\title{
Sistem Informasi Pengelolaan Data Panti Sosial Jompo Dhuafa Sayang Ummi Berbasis Website Kota Dumai
}

\author{
Delvi Elvionita ${ }^{1}$, Febrina Sari $^{2}$ \\ 1,2 Program Studi Teknik Informatika, Sekolah Tinggi Teknologi Dumai \\ Jl. Utama Karya Bukit Batrem II \\ email: delvielvionita@gmail.com
}

\begin{abstract}
ABSTRAK
Yayasan Panti Jompo Dhuafa Sayang Ummi Dumai merupakan salah satu rumah lansia yang telah memakai sistem informasi berupa pemakaian perangkat komputer dalam menjalankan aktifitas kerjanya, akan tetapi dalam penggunaannya belum secara menyeluruh karena hanya pengolahan data para lansia saja yang menggunakan perangkat komputer dengan menggunakan aplikasi perkantoran yaitu Microsoft Office. Sehingga masih banyak data seperti data instruktur, data kegiatan, data donator, dan data donasi masih dilakukan secara manual dengan dicatat di dalam buku besar. Selain itu tidak optimalnya penyebaran informasi tentang panti jompo karena informasi disampaikan hanya dari mulut ke mulut sehingga masyarakat atau donatur yang ingin mengetahui informasi tentang panti harus datang lansung ke panti atau menggunakan via telepon. Berdasarkan permasalahan tersebut, maka diperlukan suatu website yang dapat mempermudah para admin yang bekerja di Yayasan Panti Jompo Dhuafa Sayang Ummi di Dumai dalam memberikan informasi terkini seputar panti. Maka penulis merancang sebuah website dengan judul Sistem Informasi Pengelolaan Panti Sosial Jompo (Lansia) Dhuafa Sayang Ummi berbasis Website Di Kota Dumai.
\end{abstract}

Kata Kunci: Sistem, Informasi, Elderly, Website

\begin{abstract}
Yayasan Panti Dhuafa Sayang Ummi Dumai is one of the nursing homes that has used an information system in the form of the use of computer equipment in carrying out its work activities, but its use is not comprehensive because it only processes data for household purposes. elderly who use computer devices using office applications, namely Microsoft Office. So there is still a lot of data such as instructor data, activity data, donor data, and donation data are still done manually by being recorded in the ledger. In addition, the dissemination of information about nursing homes is not optimal because the information conveyed is only by word of mouth, so the public or donors who want to know information about nursing homes must come directly to the orphanage or use it by telephone. Based on these problems, a website is needed that can make it easier for admins who work at the Dhuafa Sayang Ummi Dumai Orphanage Foundation to provide the latest information about orphanages. So the author designed a website with the title Elderly Management Information System (Elderly) Based on the Website of Dhuafa Sayang Ummi in Dumai City.
\end{abstract}

Keywords: System, Information, Lansia, Website 


\section{Pendahuluan}

Perkembangan teknologi informasi saat ini tidak lepas dari pesatnya perkembangan teknologi Komputer (Sari,2017), dimana manusia terus mengikuti perkembangan teknologi guna untuk mempermudah kerja manusia dalam aktifitasnya. Setiap lembaga pasti membutuhkan suatu sistem informasi didalam aktifitas kerjanya sehingga lebih teratur dan terarah dengan waktu yang lebih efisien. Yayasan Panti Jompo Dhuafa Sayang Ummi Dumai merupakan salah satu rumah lansia yang telah memakai sistem informasi berupa pemakaian perangkat komputer dalam menjalankan aktifitas kerjanya, akan tetapi dalam penggunaannya belum secara menyeluruh karena hanya pengolahan data para lansia saja yang menggunakan perangkat komputer dengan menggunakan aplikasi perkantoran yaitu Microsoft Office. Sehingga masih banyak data seperti data instruktur, data kegiatan, data donator, dan data donasi masih dilakukan secara manual dengan dicatat di dalam buku besar, hal ini tentunya akan berpengaruh pada kesejahteraan lansia yang ada di panti jompo, hal ini seiring dengan pendapat (Maryam, 2008). Selain itu tidak optimalnya penyebaran informasi tentang panti jompo karena informasi disampaikan hanya dari mulut ke mulut sehingga masyarakat atau donatur yang ingin mengetahui informasi tentang panti harus datang lansung ke panti atau menggunakan via telepon. Sebagai solusi dari permasalahan di atas, maka penyajian sistem informasi sangat menunjang untuk mengurangi permasalahan tersebut dengan memanfaatkan kecanggihan teknologi informasi untuk mewujudkan sebuah sistem dimana sistem ini dirancang untuk memenuhi kebutuhan panti jompo seperti informasi mengenai data lansia, data instruktur, data jadwal kegiatan panti, jumlah donasi yang diperlukan dengan kata lain sistem yang lebih efektif hal ini sama dengan yang telah dilakukan oleh (Fadli \& Imtihan, 2018), system yang akan dibangun akan menyediakan kontak yang bisa dihubungi dan kotak saran dimana pengunjung bisa memberikan kritik dan saran secara online melalui web kepada pihak Yayasan Panti Jompo Dhuafa Sayang Ummi.

Penelitian ini merujuk pada beberapa penelitian terdahulu yang membahas permasalah serupa yakni (Hendriyanto, 2017) yang membahas tentang pembuatan system informasi persebaran perternakan berbasis web, berikutnya (Sulasmoro, 2016) membuat Sistem Informasi Pengelolaan Administrasi data Keuangan SD. Tentang perawatan lansia dibahas oleh (Chistanti, 2016) dan (Siregar, 2016).

\section{Metode Penelitian}

Tahapan dalam melaksanakan penelitian ini akan melewati beberapa langkah mulai dari awal hingga akhir yang dapat digambarkan sebagai berikut.

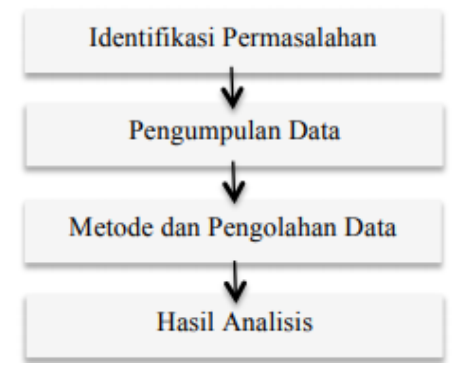

Gambar 1. Tahapan Penelitian 
Metode pengembangan dalam pembuatan Sistem ini adalah menggunakan model SDLC (Software Development Life Cycle) air terjun atau waterfall (Sari, 2018). Waterfall sering di sebut juga model sekuensial linier atau alur hidup klasik. Model air terjun menyediakan pendekatan alur hidup perangkat lunak secara sekuensial atau terurut di mulai dari analisis, desain, pengkodean dan diakhiri implementasi.

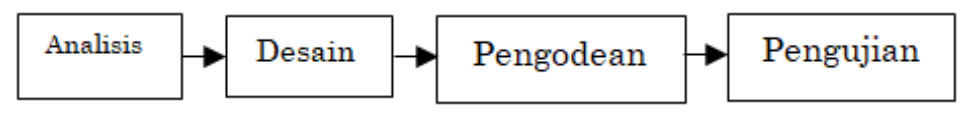

Gambar 2. Model Waterfall

\section{Hasil dan Pembahasan}

Pembuatan Sistem Informasi Pengelolaan Panti Sosial Jompo (Lansia) Dhuafa Sayang Ummi berbasis Website Di Kota Dumai menggunakan Unified Modelling Language (Sujono, 2021) dalam merancang system. dimulai dengan membuat rancangan sistem.

\section{Rancangan Sistem}

Tahap ini merupakan tahap pembahasan dari sistem yang akan dibangun. Rancangan sistem berarti menggambarkan tampilan dan cara kerja dari sistem secara global.

\section{Use Case Diagram}

Untuk melihat prilaku atau deskripsi dari urutan aksi yang dilakukan oleh aplikasi untuk memberikan hasil kepada aktor maka digunakan use case diagram. Adapun use case diagram Sistem Informasi Pengelolaan Panti Jompo Dhuafa Sayang Ummi Berbasis Website di Kota Dumai sebagai berikut :

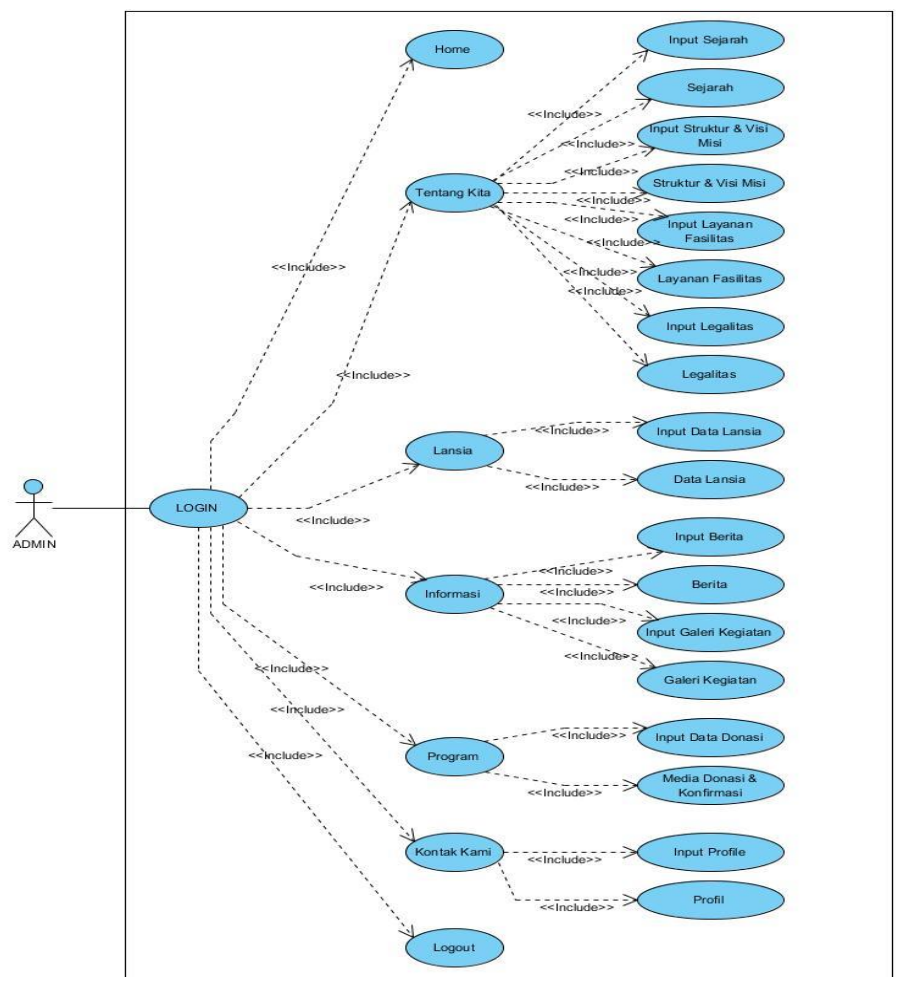

Gambar 3. Use Case Diagram 


\section{Class Diagram}

Class Diagram adalah sebuah spesifikasi yang jika diinstansiasi akan menghasilkan sebuah obyek dan merupakan inti dari pengembangan dan desain berorientasi obyek. Sebuah class diagram digunakan untuk menunjukkan keberadaan dari kelas dan hubungannya di dalam pandangan logic dari sebuah sistem

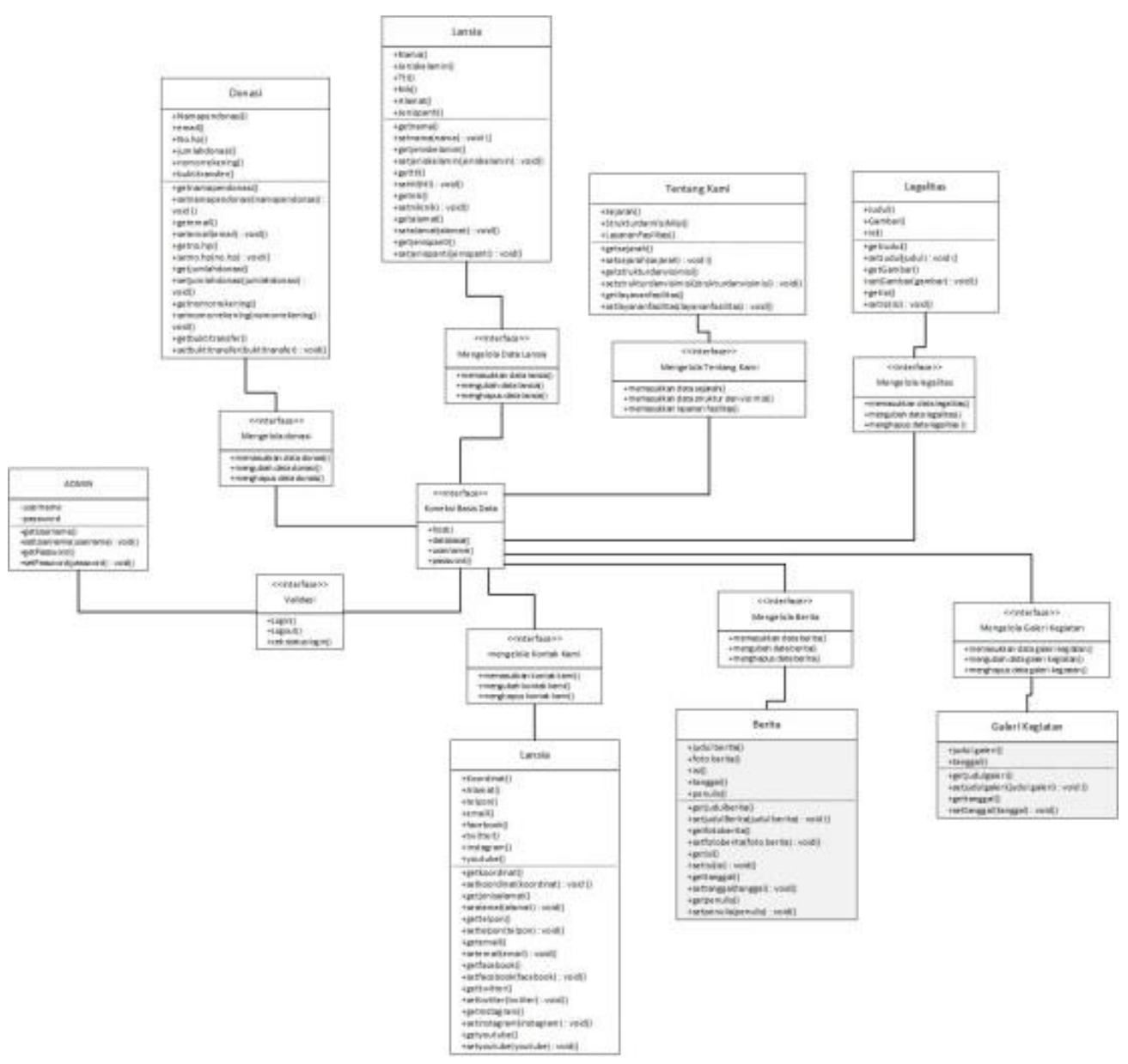

Gambar 4. Class Diagram

\section{Implementasi Sistem}

Sistem ini akan diimplementasikan di Yayasan Panti Jompo Dhu'afa Sayang Ummi untuk mempermudah dalam mengenalkan dan memberikan informasi seputar panti jompo kepada masyarakat, dan juga mempermudah pihak Panti Jompo dalam mendapatkan bantuan untuk para lansia dalam binaan maupun luar binaan, berikut hal-hal yang terdapat dalam system informasi yang dibangun.

\section{Halaman Login}

Halaman login sebagai akses masuk ke dalam system dengan menggunakan username dan password. User adalah orang yang siap memakai sebuah komputer yang sudah disiapkan oleh system analisis dan dibawah pengawasan admin, berikut tampilan halaman login jika berhasil. 
Unitek : Jurnal Universal Teknologi

Vol. 14 No.1 Januari-Juni 2021

e-ISSN : 2580-2582, p-ISSN: 2089-3957

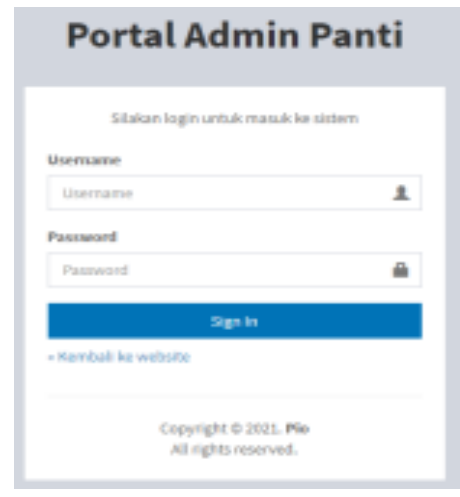

Gambar 5. Halaman Login

\section{Halaman Home}

Halaman Home sebagai akses untuk langsung bisa melihat tampilan Website ke dalam Sistem Informasi Yayasan Panti Jompo Dhu'afa Sayang Ummi Berbasi Website Kota Dumai. Berikut tampilan awal website.

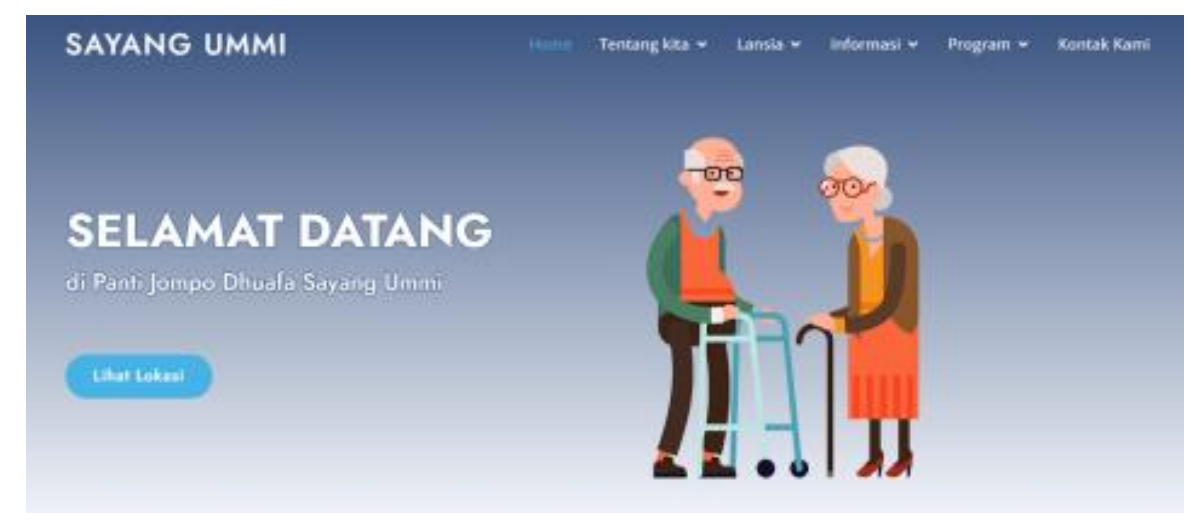

Gambar 6. Halaman Home

\section{Halaman Beranda}

Halaman ini akan berisikan tampilan menu sejarah panti, Struktur \& Visi Misi, dan halaman layanan fasilitas. Hal ini dapat dilihat pada gambar berikut.

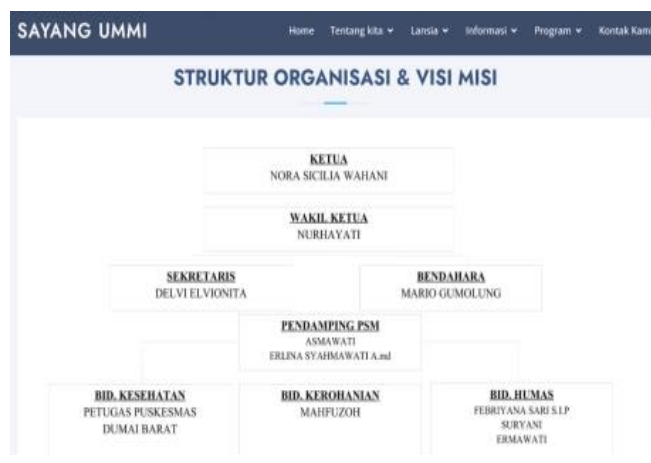

Gambar 7. Halaman Struktur

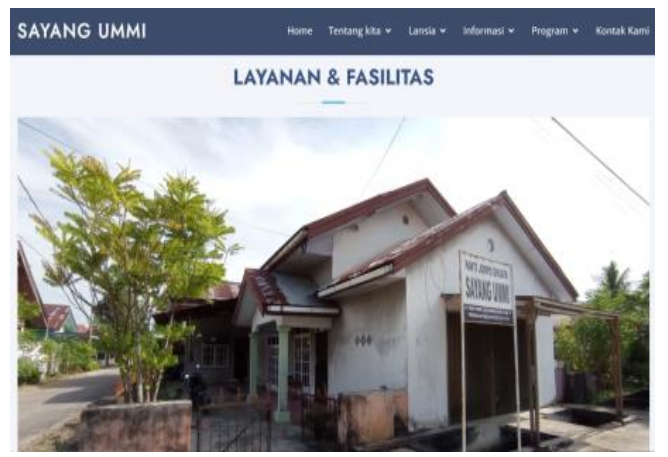

Gambar 8. Halaman Layanan 
Unitek : Jurnal Universal Teknologi

Vol. 14 No.1 Januari-Juni 2021

e-ISSN : 2580-2582, p-ISSN: 2089-3957

\section{Halaman Input Legalitas}

Halaman input Legalitas sebagai akses untuk memasukkan data legalitas yayasan pada Sistem Informasi Yayasan Panti Jompo Dhu'afa Sayang Ummi Berbasi Website Kota Dumai.

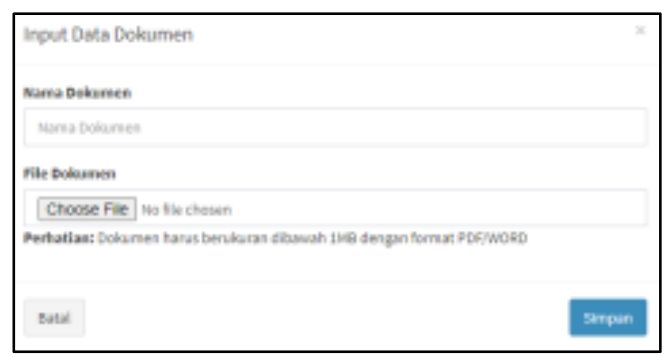

Gambar 9. Halaman Input Legalitas

\section{Halaman Tampilan Legalitas}

Halaman ini menyediakan tabel untuk melihat data legalitas yang telah di inputkan melalui form input legalitas.

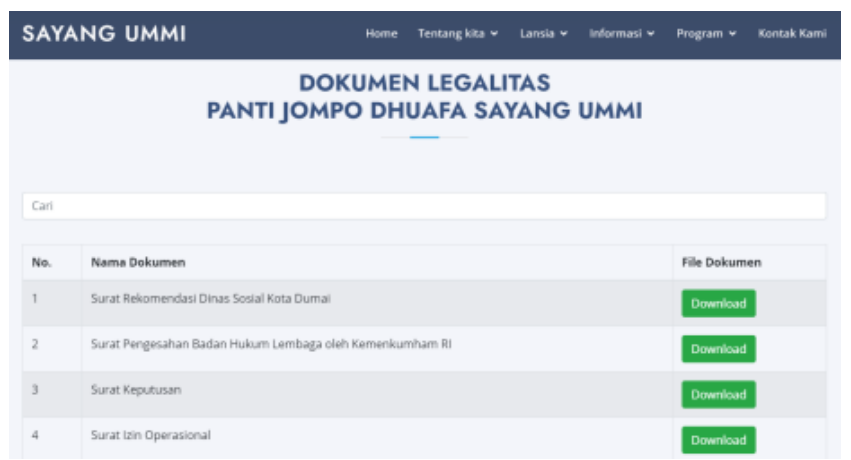

Gambar 10. Halaman Tampilan Legalitas

\section{Halaman Input Data Lansia}

Halaman input Data Lansia sebagai akses untuk memasukkan data lansia pada Sistem Informasi Yayasan Panti Jompo Dhu'afa Sayang Ummi Berbasi Website Kota Dumai.

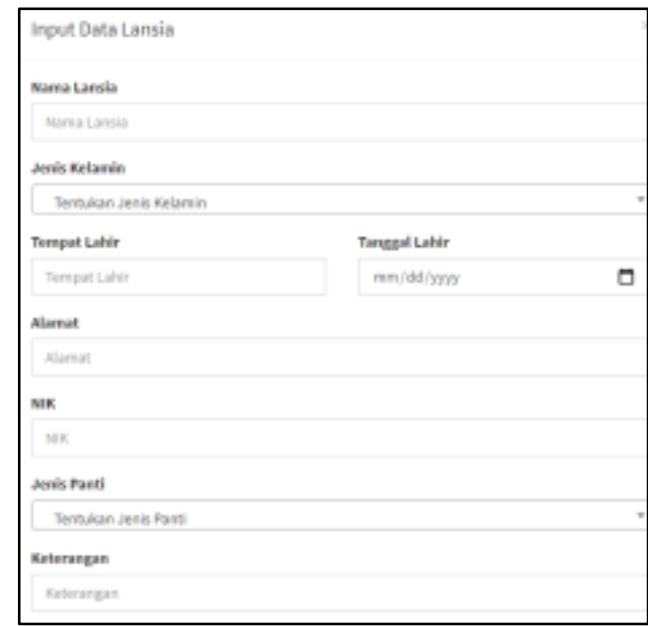

Gambar 11. Form Input Data Lansia 
Unitek : Jurnal Universal Teknologi

Vol. 14 No.1 Januari-Juni 2021

e-ISSN : 2580-2582, p-ISSN: 2089-3957

\section{Halaman Tampilan Data Lansia}

Halaman ini menyediakan tabel untuk melihat data lansia yang telah diinputkan pada form input data lansia.

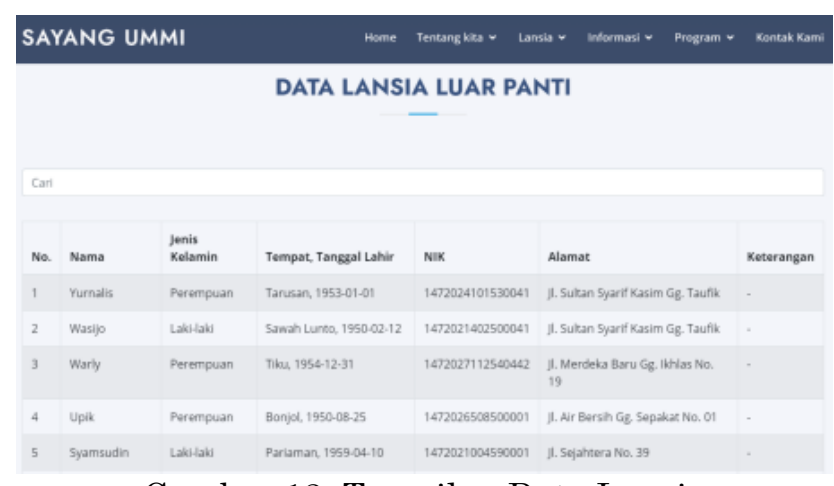

Gambar 12. Tampilan Data Lansia

\section{Halaman Tampilan Galeri Kegiatan}

Halaman ini adalah akses untuk bisa melihat tampilan menu galeri kegiatan yang telah dilaksanakan baik di dalam panti maupun di luar panti pada Sistem Informasi Yayasan Panti Jompo Dhu'afa Sayang Ummi Berbasi Website Kota Dumai.

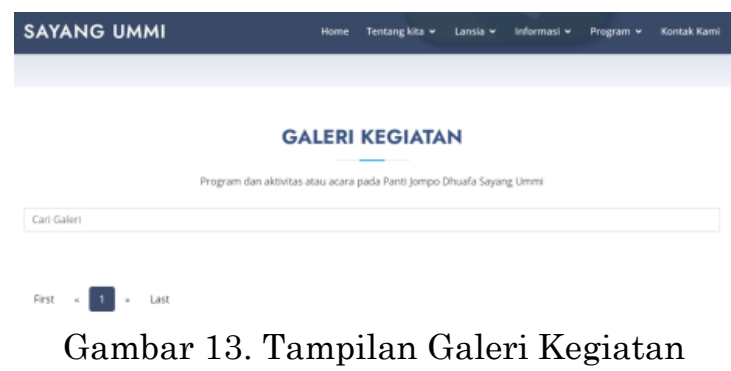

\section{Halaman Input Donasi (Admin)}

Halaman input Data Donasi (Admin) sebagai akses untuk memasukkan data donasi atau bantuan yang diberikan masyarakat umum atau dari pihak institusi pemerintah maupun swasta yang diserahkan langsung ke panti maka admin akan menginputkan data donasi ini ke system menggunakan form input data donasi.

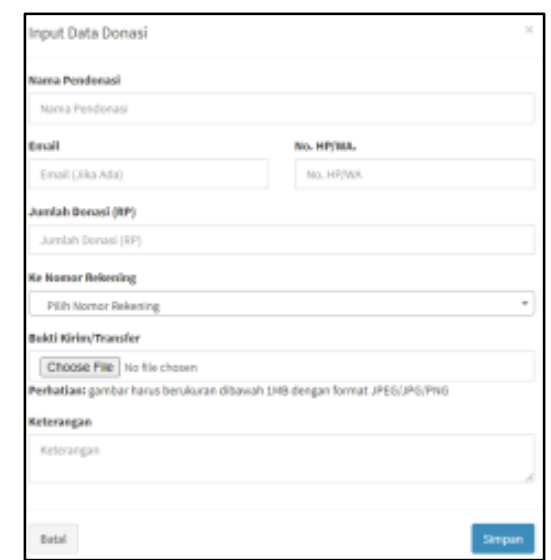

Gambar 14. Tampilan Form Input Donasi Admin 


\section{Halaman Input Donasi (Masyarakat)}

Halaman input Data Donasi (masyarakat) sebagai akses untuk memasukkan data donasi yang dilakukan oleh masyarakat secara langsung ke Sistem Informasi Yayasan Panti Jompo yang hanya bisa diakses oleh masyarakat atau donatur.

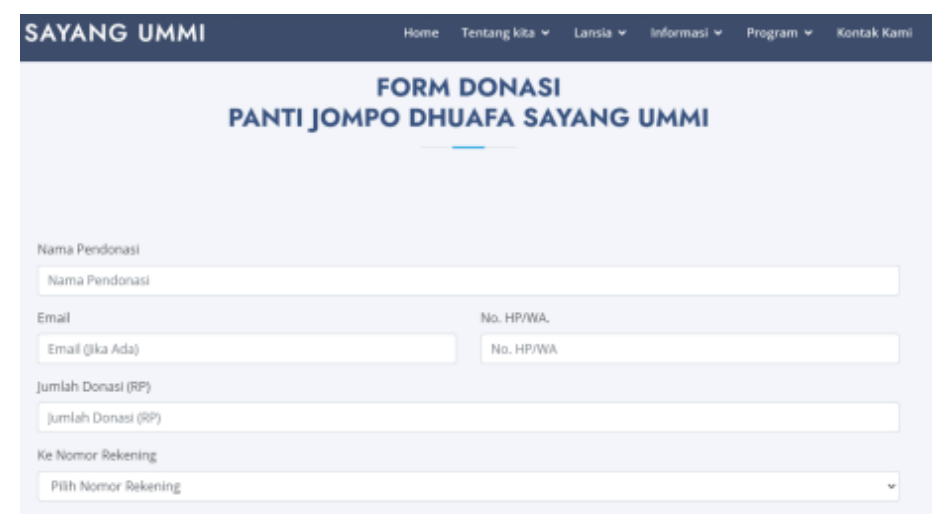

Gambar 15. Tampilan Form input Donasi Masyarakat

\section{Halaman Tampilan Donasi}

Halaman ini menyediakan tabel untuk melihat data donasi yang telah diinput oleh admin termasuk donasi yang telah di input oleh masyarakat secara langsung melalui web panti jompo sayang ummi.

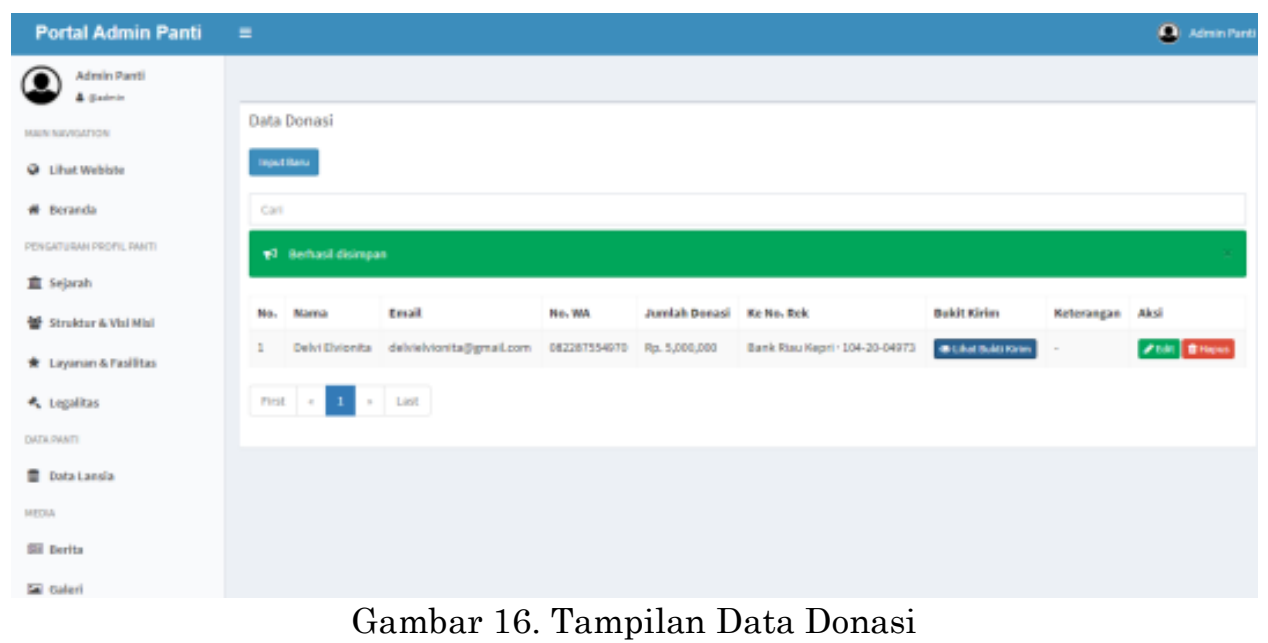

\section{Simpulan}

Sistem Informasi Pengelolaan Panti Sosial Jompo Dhuafa Sayang Ummi Berbasis Website Kota Dumai telah berhasil dibangun dan diimplementasikan, berdasarkan pengamatan dengan adanya system informasi ini admin atau petugas Panti Jompo sangat terbantukan, proses pengolahan data panti lebih cepat. Pengolahan data donasi lebih trasparan. Selain itu admin dapat menampilkan informasi seputar panti dengan lebih cepat dan tepat jika dibutuhkan. Sistem Informasi Pengelolaan Panti Jompo Dhuafa Sayang Ummi Berbasis Website ini juga dapat mempermudah masyarakat dalam mencari informasi seputar Panti Jompo dan menyalurkan bantuan atau berdonasinya. 


\section{Daftar Pustaka}

Cristanty, Mela \& Suzy Azeharie (2016), Studi Komunikasi Interpersonal Antara Perawat Dengan Lansia Di Panti Lansia Santa Anna Teluk Gong Jakarta. Jurnal Komunikasi ISSN 2085-1979, EISSN 25282727 Vol. 8, No. 2, Hal 170 178.

Fadli, S., \& Imtihan, K. (2018). Analisis Dan Perancangan Sistem Administrasi Dan Transaksi Berbasis Client Server. Jurnal Informatika Dan Rekayasa Elektronik, 1(2), 7. https://doi.org/10.36595/jire.v1i2.54.

Hendiyanto, Achmad., Zainul Arham, \& Eva Khudzaeva (2017). Rancang Bangun Sistem Informasi Spasial Persebaran Peternakan Berbasis Web (Studi Kasus: Kota Depok). Jurnal Sistem Informasi, 10(2), 2017, P-ISSN 1979-0767.

Maryam, R. Siti, dkk. (2008). Mengenal Usia Lanjut dan Perawatannya. Jakarta : Salemba Medika.

Sari, Febrina., Lidya, Putri. (2017). Mobile Application Reminder of SPP Payment Schedule's and School Activities Information Based SMS Gateway. Journal of Telecommunication, Electronic and Computer Engineering (JTEC). Vol. 9, No.3-8. Pages.27-31

Sulasmoro, Arfan Haqiqi, P. D. A. (2016). Sistem Informasi Pengelolaan Administrasi Keuangan Pada SD Muhammadiyah. Smart Comp, 5(09), 149-153. http://www.ejournal.poltektegal.ac.id/in dex.php/smartcomp/article/view/401/37 8

Sujono, Maxrizal \& Lili Indah Sari (2021). Analisis dan Perancangan Sistem Informasi Pengelolaan Data Administrasi Sekolah Dasar Islam Terpadu. Jurnal SATIN - Sains dan Teknologi Informasi Vol. 07, No. 01, pp. 01-11. ISSN: 2527-9114, DOI 10.33372/stn.v7i1.70

Sari, Febrina., Mustazzihim Suhaidi \& Elisa Hafrida. (2020). Implementasi Aplikasi Pengolah Data Akseptor Suntik Di Puskesmas. Jurnal Madani : Indonesian Journal of Civil Society. Vol.2 No.2, Hal. 1-7. e-ISSN : 2686-035X, p-ISSN :2686-2301.

Yafrinal Siregar, (2016). Gambaran Faktor-Faktor yang Berhubungan dengan Kejadian Arthritis Rheumatoid pada Lansia di Panti Jompo Guna Budi Bakti Medan Tahun 2014, Jurnal Ilmiah Keperawatan IMELDA Vol. 2, No. 2. 